\title{
O DWÓCH GŁÓWNYCH WARIANTACH LOKOWANIA PERFORMANSU MEDIALNEGO
}

\author{
Abstract \\ ON THE TWO MAIN VARIANTS OF LOCATING MEDIA PERFORMANCE
}

The article presents the two main variants of media performance on the basis on their location. The first one is a frame for ongoing social phenomena. The key concept illustrating this type is Piotr Sztompka's theory of social becoming, and specifically the term praxis. The influence of descriptions of the surroundings, including the ideological surroundings, on a completed piece as well as on practical and discursive consciousness, have also been taken into consideration. The other variant of media performance is related to creating new situations and media environment according to the instruction for building the agenda and in compliance with precise requirements for the structure. The text contains: the descriptions of qualities of both variants, a comparison to other performance genres, by analogy and amplification, and reflections on the feedback mechanism, the influence, and the agency associated with all sorts of media performance. The category of delegated performance as a media performance has been discussed here in more detail. The text adopts the processual perspective, which, according the author, delivers a far more integrated understanding of such cultural aspects as media performances, their means and determinations of creation, the influence they have, and the changes they undergo, which remain in tight relation to technological progress.

Key words: media performance, delegated performance, praxis, device

\section{Wprowadzenie}

Artykuł ma na celu uporządkowanie podstawowego rozumienia zjawiska performansu medialnego $\mathrm{z}$ perspektywy jego umiejscowienia $\mathrm{w}$ fenomenie społecznym oraz ukazanie medialnych jakości z perspektywy studiów performatywnych w zwięzłej formie. Performans medialny rozumiany jest tutaj jako komunikat medialny ze świadomym użyciem technologii oraz z założeniem, że będzie on udostępniany odbiorcy lub szerszej publiczności. Jacek Wachowski, autor polskiego podręcznika do 
performatyki, zalicza performans medialny do jednego $\mathrm{z}$ dwóch wariantów performansów technologicznych, gdzie technologia pozostaje jedynie narzędziem ${ }^{1}$. Różne rodzaje perfomansów przenikają się ze sobą, najistotniejsze pozostaje jednak to, które elementy będą przeważać, $\mathrm{z}$ jakim kontekstem mamy do czynienia i gdzie jest usytuowana publiczność 2 . Stąd narzędzie, które w rezultacie będzie ramą dla działania (pozostającego tematem performansu), będzie decydowało o przyporządkowaniu go do kategorii performansu medialnego, i w ten sposób będzie można wnioskować o jego własnościach. Transmisja radiowa wydarzenia na żywo będzie performansem medialnym, ale spektakl Wiedźmy w reżyserii Krzysztofa Jasińskiego w Teatrze Stu z wykorzystaniem multimedialnych projekcji pozostanie performansem artystycznym, w którym zostały wykorzystane nowe technologie.

Inny klasyczny już w zakresie studiów performatywnych teoretyk, Jon Mackenzie, przypomina o najważniejszych wyróżnikach tego rodzaju działań, które wyprowadzić można wprost $\mathrm{z}$ angielskiego tłumaczenia zaskakująco pojemnego pojęcia: performance. Mowa tu o: wydajności czy efekcie ściśle związanym z jakością? To właśnie technologie umożliwiły eksplozję nowych form przekazu, które zaczęto projektować tak, aby żonglować naszą uwagą. Można ją więc zawłaszczać całkowicie lub kierować nią i koncentrować na starannie obmyślonym aspekcie szerszej sytuacji społecznej, kulturowej, w tym też organizacyjnej. To zjawisko, ściśle związane z rozwojem cywilizacyjnym, umożliwiło postulat powszechności dostępu do informacji, utrwalania, dowolnego ich formatowania i zestawiania. Do akcji wcześniej niedostępnej dla wielu - zaproszono widzów o niespotykanej dotąd liczbie. Aktualnym przykładem mogą być choćby każde mistrzostwa świata w piłce nożnej, które są transmitowane nawet przez te telewizje, których krajowe drużyny nie biorą udziału w rozgrywkach. Podniosła atmosfera i silne emocje związane są nie tyle z samą grą, jej stawką, ile z przeżyciem sytuacji na żywo.

W dalszej części artykułu zaprezentuję dwie propozycje najważniejszych moim zdaniem umocowań performansów medialnych. Jedno z nich będzie się wiązało z wkroczeniem performansów medialnych do dziejących się już sytuacji społecznych - do sytuacji stawania się społeczeństwa i udostępniania jej innej publiczności. Drugie lokowanie pojawi się wraz z kreowaniem nowych sytuacji i przestrzeni, w tym nowych miejsc, jak np. studio czy sala do wideokonferencji, na potrzeby przekazu komunikatu. Po przedstawieniu obu umiejscowień odniosę się do aspektu sprzężenia zwrotnego - omawianego nierozłącznie z innymi formami performansu. Dalej przejdę do jakości i właściwości obu wcześniej zaproponowanych umiejscowień performansów medialnych. W tym celu zastosuję tu analogie wykorzystywane przez studia performatywne do badania cech performansów.

1 Według klasyfikacji Jacka Wachowskiego inny wariant performansu technologicznego to pokaz osiągnięć samych narzędzi: popis wydajności, osiągów i efektów najnowszych wynalazków.

2 J. Wachowski, Performatyka, Słowo/Obraz Terytoria, Gdańsk 2011, s. 47.

3 J. McKenzie, Performuj albo... Od dyscypliny do performansu, thum. T. Kubikowski, Universitas, Kraków 2011. 
Skorzystam z właściwości sztuki performance jako tej bezpośredniej i danej oraz, $\mathrm{w}$ drugim wariancie, $\mathrm{z}$ właściwości sztuk performatywnych jako form reżyserowanych. Poprzedzę to formalnie obowiązkowym rozróżnieniem, które na gruncie rozważań nad etymologią słowa performance budzi często wątpliwości praktyków. Inspirowanie się charakterystyką niezwiązanych ze sobą zjawisk może nie być oczywiste, a nawet w pierwszym odruchu nieprzekonujące - buduje jednak uzasadnienie dla pracy teoretycznej nad rozwojem perspektywy procesualnej. Oprócz wnioskowania na zasadach analogii dotyczącej dwóch wariantów nawiążę też do dwóch szczególnie ciekawych jakości performansów medialnych: liminautycznej i autotelicznej. W całości tej pracy wykorzystam też amplifikacje - odwoływanie się do bardziej uniwersalnych mechanizmów i teorii społecznych, aby w ten sposób wnioskować o właściwości performansów medialnych ${ }^{4}$.

Na koniec przeprowadzę krótką dyskusję dotyczącą zjawiska performansu delegowanego w aspekcie przekazów medialnych z wykorzystaniem przykładu szczególnie działającego na emocje, jakim jest relacjonowanie ataku terrorystycznego. Przykład odniosę do zaproponowanych w tekście dwóch wariantów lokacyjnych.

\section{Pierwszy wariant lokacyjny performansu medialnego: towarzyszenie społeczeństwu przy „codziennych czynnościach”}

Socjolog Piotr Sztompka, wykładając swoją teorię stawania się społeczeństwa, przywołuje Margaret Archer oraz jej sugestię zwrócenia uwagi na moment styku struktur i podmiotów oraz funkcjonowania i działania ${ }^{5}$. To tam dochodzi do zdarzeń społecznych, na które $\mathrm{w}$ tym przypadku nakłada się performans medialny jako rama. To właśnie mam na myśli, pisząc o kontekście, na który zwraca się narzędziową uwagę w przypadku performansów medialnych. Nie jest to kontekst nieruchomy, jak np. instytucja bez związków z ludźmi, dla których spełnia potrzeby, nie jest to też pojedyncza zbiorowość wyrwana ze swojego otoczenia relacji. Chodzi najczęściej o inne aspekty żywej kultury; innego typu performanse, które stają się materiałem dla tych medialnych (np. performanse religijne, obrzędy, rytuały, święta, debaty publiczne, wybory, działania wojskowe, rewolucje, protesty, mecze, zawody, gry, zabawy, negocjacje). Ten wariant lokacyjny odnosi się więc do sytuacji „stawania się społeczeństwa”, do których się dociera, aby w „oryginalnym” otoczeniu medialnie mu towarzyszyć.

Sztompka nawiązuje do Marksa, Gramsciego i Lukácsa, nazywając zachodzące zdarzenia terminem praxis - $\mathrm{w}$ którym spotykają się funkcjonowanie i działanie jako synteza tego, co dzieje się w społeczeństwie w ogóle, mając na myśli

\footnotetext{
${ }^{4}$ J. Wachowski, Performatyka, dz. cyt., s. 94.

${ }^{5}$ P. Sztompka, Socjologia zmian społecznych, Znak, Kraków 2005.
} 
najprawdziwszą rzeczywistość świata społecznego ${ }^{6}$. Sama potencjalność w teorii Sztompki będzie syntezą i będzie się wiązać tylko ze zdolnością do działania podmiotów oraz zdolnością do funkcjonowania struktur, ale jeszcze nie $z$ realizacją. Samo zdarzenie, jeśli do niego dojdzie, jest już tematem do przekazu i to ono jest interesujące $\mathrm{z}$ perspektywy tego wariantu umiejscowienia performansów medialnych. Według Sztompki musi istnieć coś, co jest realizowane i manifestowane; zbiór zdolności, skłonności, tendencji immamentnych pozwalających na zaistnienie pra$x i s$, która jest manifestowana w zdarzeniach społecznych:

Jest ono ponownie zbiegnięciem się aktualizacji zachodzącej na różnych poziomach, fuzji rozwoju struktur i mobilizacji podmiotów [...] „zdarzanie się” - jest tylko możliwe, czasem prawdopodobne, ale nigdy konieczne ${ }^{7}$.

Kontekst dla zdarzeń to przyroda lub „otoczenie ideologiczne”. W tym przypadku będzie ono również otoczeniem dla performansów medialnych, powstających na bazie zdarzeń. Szczegółowy wpływ środowiska nie jest trudno sobie wyobrazić. Mamy tu, jak pisze autor teorii, do czynienia nie tylko z wpływami zewnętrznymi, lecz także wewnętrznymi, dotyczącymi cech biologicznych czy wyposażenia genetycznego, sprawności fizycznej itp.

Drugie otoczenie przywoływane przez socjologa omawiane jest na bazie prac Anthony’ego Giddensa związanych ze świadomością i zdolnością ludzi do rozumienia swojego działania, w tym celowości i motywacji, czy to prawdziwej, czy fałszywej. W tym modelu będziemy mieli nawiązanie do świadomości praktycznej i dyskursywnej, a dyskursywna odnosić się będzie do monitorowania samego monitorowania swojego zachowania w wymiarze jednostkowym i zbiorowym.

Erving Goffman definiował performans jako wszelką działalność przebiegającą w obecności obserwatorów, wpływającą na innych uczestników, ale performansem będzie także świadomość siebie w działaniu. W kontekście tej teorii świadomość dyskursywna będzie szczególnie znaczącym aspektem dla performansu medialnego $^{8}$. Dla ścisłości przypisujemy ją, pisze Sztompka, nie tylko jednostkom, lecz także grupom. Mówimy więc o kulturze grupy, o wyobrażeniach zbiorowych, przekonaniach, tradycjach. Autor traktuje te struktury jako zewnętrzne środowisko podmiotowości. Od tego zależeć będzie, jaka realizacja (praxis) jest możliwa. Są przykłady drastyczne, w których ograniczenia nakładane przez kontekst ideologiczny prowadzą do wykształcania się totalitaryzmów, fundamentalizmów, tyranii - wylicza socjolog. Są też mniej drastyczne, ale wywierające równie ciekawy wpływ i objawiające się w realizacjach. Pisał o nich choćby Giorgio Agamben, formułując koncepcję

6 Tamże.

7 Tamże.

8 E. Goffman, Człowiek $w$ teatrze życia codziennego, tłum. H. Datner-Śpiewak, P. Śpiewak, Wydawnictwo KR, Warszawa 2000, s. 45. 
urządzeń, których autorami są ludzie ${ }^{9}$. Należały do nich dyskursy, instytucje, struktury architektoniczne, regulaminy, prawa, wypowiedzi naukowe, filozoficzne, filantropijne, pismo, literatura czy szkolnictwo ${ }^{10}$. Mają one nie tylko zdolność manipulowania stosunkami władzy, lecz także, co szczególnie interesujące w kontekście perfomansu medialnego: zabezpieczają gesty. Są wynalazkami człowieka, które przejmują nad nim kontrolę, a już na pewno wywierają wpływ i mają moc performatywną. Siła urządzeń jest odpodmiotawiająca i grozi dyktaturą automatyzmu, mówi filozof. Warto jednak zwrócić uwagę na aspekt samej realizacji.

Potencjalność performansu medialnego $\mathrm{w}$ takim otoczeniu nasuwa się od razu - łatwo wyobrazić sobie realizację $\mathrm{w}$ formie potwierdzania takich porządków społecznych, ale też przykłady medialnych performansów oporu, opatrzone krytyką komentatora, niezgodą czy dodatkową interpretacją pozostającą w kontrze do zjawiska, któremu rejestracja/przekaz towarzyszy. Pozostaje też trzecia potencjalność, zdystansowana i oddająca ocenę odbiorcy - możliwe, że w realizacji medialnej to ona pozostaje najtrudniejsza do osiągnięcia, jeśli ma być zamierzona i zaplanowana. Niezbędna będzie tu zdystansowana, wręcz badawcza postawa samego zespołu konstruktorów jako osób, które posiadają intencję braku sądzenia. Jest to trudniejsze do osiągnięcia, gdy sami rejestrujący pozostają emocjonalnie zaangażowani w otoczenie, w którym pełnią inne role. Pokusa kształtowania odbioru rzeczywistości może być kusząca. Szczególnie gdy pracuje się w miejscu, do którego dostęp dla innych jest ograniczony lub gdy bierze się pod uwagę przewidywane oczekiwania odbiorcy. Przekazujący ma więc pewną formę władzy z uwagi na wiedzę na temat wydarzenia, do której zyskał dostęp, dzięki zanurzeniu się w mniej dostępny kontekst. Sztompka pisze, że kondycja praxis jest na tyle żywa i otwarta, że przekonanie może zostać wystawione na próbę.

To, w praxis i przez praxis, dowodząc swojej nieefektywności, nieskuteczności lub antyludzkich skutków, rozpadają się i znikają struktury ideologiczne i doktrynalne, podważone zostają utopie i dogmaty, mimo że może to trwać przez pokolenia lub wieki, jako że zasada inercji działa tu ze szczególną bezwzględnością ${ }^{11}$.

Świadomość nie jest jednak niezawodna, podobnie jak zdolność przewidywania i programowania wszystkich skutków, w tym przypadku performansów medialnych.

9 Agamben. Przewodnik Krytyki Politycznej, Wydawnictwo Krytyki Politycznej, Warszawa 2009, s. 94-95.

${ }_{10}$ Agamben rozwija koncepcję urządzeń za Foucaultem, który przedstawia urządzenia jako złożoną sieć elementów przynależną do różnych systemów władzy.

11 P. Sztompka, Socjologia zmian społecznych, dz. cyt., s. 211. 


\section{Drugi wariant lokacyjny performansu medialnego - nowe sytuacje}

Drugi wariant lokacyjny będzie związany z „gabinetowością” performansów medialnych, $\mathrm{z}$ organizacją przekazu w miejscu specjalnie do tego stworzonym. Będzie to miejsce dosłowne, jak np. studio, lub wirtualne, jak sieć internetowa. Przykładami tego wariantu będą: konferencje prasowe, reklamy, niektóre performanse edukacyjne, artystyczne, eksperymenty medialne, wideoinstalacje, słuchowiska, webinary, audycje, aktywności w mediach społecznościowych.

Można dokonać tu rozwinięcia na typy sytuacji, wokół których projektuje się performance medialny i zebrać ich techniki tworzenia w oparciu o szczegółowe analizy dokonane przez węższe specjalizacje (jak np. retoryka, public relations, agendy prezentacji medialnych, reklamę, serwisy informacyjne). W aspekcie performatywnym szczególnych inspiracji w aspekcie budowania struktur według Jacka Wachowskiego dostarczają teatrolodzy ${ }^{12}$. Metafora teatru i dla drugiego wariantu performansów medialnych dostarczy właściwych narzędzi interpretacyjnych. Mamy więc kostiumy i rekwizyty oraz ściśle zaplanowane role, ich znaczenia i funkcje. Jest też wymiar sceny i kulis. Szczególnie wymiar kulis został wnikliwie opisany przez Goffmana przez zwrócenie uwagi na to, jak różnie zachowuje się człowiek w tych dwóch wymiarach. Kulisy są fabryką złudzeń, mieszaniną niezestawionych jeszcze ze sobą rekwizytów, niezrealizowaną potencjalnością, otwartością, swobodą, rezerwatem nieformalności, brakiem poprawności i kontroli. To tam pracuje się nad odpowiednim dobraniem maski, $w$ tym maski medialnej ${ }^{13}$. Tam też opracowuje się porządek spraw, jak odnoszą się do tego badacze teorii masowego komunikowania.

Budowanie porządku spraw odnosi się do złożonego procesu w obszarze mediów publicznych odpowiedzialnego za ustalanie tematów, które powinny skupiać uwagę życia publicznego. Dwójka badaczy, Shanto Iyengar i Donald R. Kinder, zajęła się wyodrębnieniem elementów składowych tego procesu ${ }^{14}$. Należały do nich: ustalanie porządku spraw (zwrócenie uwagi na związek przyczynowy między porą wyświetlania konkretnego komunikatu a ocenami dokonywanymi później przez publiczność, np. w kwestiach spraw państwa czy społeczeństwa), sugestywność relacji informacyjnych - Goffmanowskie dramatyzowanie performansu medialnego. Dalej skupianie uwagi na stronie afektywnej, na osobie czy konkretnej sytuacji, która odwraca uwage od konkretnego problemu. Inne komponenty to: pozycja w programie - wykorzystywanie przekonania o tym, że informacja relacjonowana jako pierwsza jest ważniejsza. Pierwszeństwo uwagi Iyengara ilustruje na przykładzie: „O ile ustalanie porządku spraw odnosi się do wpływu relacji informacyjnych na postrzeganie ważności poszczególnych kwestii państwowych, o tyle pierwszeństwo uwagi oznacza wpływ relacji informacyjnych na znaczenie poszczególnych kwestii

12 J. Wachowski, Performatyka, dz. cyt., s. 35.

13 E. Goffman, Człowiek $w$ teatrze życia codziennego, dz. cyt.

${ }^{14}$ S.J. Baran, D.K. Davis, Teorie komunikowania masowego, tłum. A. Sadza, Wydawnictwo Uniwersytetu Jagiellońskiego, Kraków 2007. 
w dokonywaniu ocen politycznych"15. Powstawanie takich teorii świadczy o zainteresowaniach nie tylko monitorowaniem zachowań, ale już monitorowaniem samego monitorowania performansów medialnych. Piotr Sztompka pisze o ogólnej tendencji historycznej ewoluującej w kierunku wyższego poziomu kontroli ${ }^{16}$. Giddens o refleksyjności samej refleksyjności, będącej znakiem naszych czasów.

\section{Sprzężenie zwrotne w performansie medialnym}

Wspomniany wcześniej Sztompka przytacza użyteczny i tutaj cytat z prac Roberta K. Mertona „Reagujemy nie tylko na obiektywne cechy sytuacji, ale również, a czasami przede wszystkim, na znaczenie, jakie ta sytuacja ma dla nas" ${ }^{17}$. W tym celu instytucje medialne mogą decydować się na badanie recepcji własnych komunikatów i dostosowywanie swoich działań do wyników. W teorii masowego komunikowania pojęcie widowni jest wyabstrahowane. Denis McQuail dzieli je na cele badania ze względu na media i ze względu na widownię. Do celów ze względu na media należą: pomiar zasięgu oddziaływania, wybory widowni, poszukiwanie nowych, testowanie. Ze względu na widownię: celem jest sam obowiązek służby publicznej, ocena wartości pracy mediów, badanie motywacji publiczności, badanie nadawania znaczeń, badanie kontekstu ${ }^{18}$. Sztompka sprawę interpretacji zamyka w polu zasobów, które tworzy świadomość indywidualna i społeczna ${ }^{19}$.

Może ona utrzymywać ludzi w nieświadomości pewnych ograniczeń i możliwości lub otwierać im na nie oczy. Może ich zwodzić, dostarczając nieodpowiednich narzędzi intelektualnych służących do pojmowania rzeczywistości lub rozwiewać iluzje, oferując ostre pojęcia krytyczne. Tak więc warunki naturalne, w ich ograniczającym lub wyzwalającym wpływie na podmiotowość, są w dużym stopniu zapośredniczone przez otoczenie ideologiczne ${ }^{20}$.

To samo tyczy się narzędzi proponowanych przez naukę na przestrzeni wieków. Ktoś i teraz może opracować przeciwurządzenie, mówiąc językiem agambenowskim, które podważy kategorie performansu, w tym też medialnego, i układania interpretacji świata mediów pod aspekt żywy i procesualny. Zaproponuje coś bardziej przekonującego, co wyzwoli nas z ograniczeń i tak już szerokiego pojęcia to oczywiście projekcja, która nie musi się spełnić, ale najtrafniej będzie oddawała sedno tej myśli.

15 Tamże.

16 P. Sztompka, Socjologia zmian społecznych, dz. cyt.

17 R.K. Merton, Social Research and Practicing Professions, Abt Books, Cambridge 1982.

18 D. McQuail, Teoria komunikowania masowego, tłum. M. Bucholc, A. Szulżycka, Wydawnictwo Naukowe PWN, Warszawa 2007, s. 390-410.

19 P. Sztompka, Socjologia zmian społecznych, dz. cyt., s. 211-212.

20 Tamże. 
Myśląc o sprzężeniu zwrotnym jako o zjawisku na większą skalę w przypadku performansów medialnych, nasuwa się skojarzenie z koncepcjami na temat oddziaływania technologii na porządek społeczny i wywoływania głębokich zmian w kulturze. Zwolennikiem tego transformacyjnego podejścia był już w latach 60 . ubiegłego wieku Marshall McLuhan ${ }^{21}$. Badacz zwrócił uwagę nie tylko na fakt przekształcania naszego doświadczenia, samych siebie, społeczeństwa, lecz także na to, że ten wpływ zdaje się mieć większe znaczenie niż sama treść komunikatów: „Środek przekazu jest przekazem"22. Obszerniej przedstawił tę zależność wraz ze współautorami w późniejszej książce o tym samym tytule. Estetyka performansu medialnego też komunikuje. Świeża i oryginalna nasuwa skojarzenia $\mathrm{z}$ aktualnością, zwraca więc uwagę, rości sobie prawo do pierwszeństwa uwagi.

Teorie McLuhana spotkały się z pochwałami, ale i krytyką. Zarzucano nieweryfikowalność teorii i niemożliwość badania czegoś takiego jak doświadczenie i wpływ mediów na doświadczenie oraz nieliniowy sposób myślenia. Z początkiem $\mathrm{XXI}$ wieku, w dobie rozwoju nowych mediów wróciły one jednak do łask, by dostarczać nowych inspiracji. Wpływ na przekształcenia współczesnej kultury okazał się w końcu bezprecedensowy.

\section{Jakości dwóch wariantów}

W performansach medialnych dostrzegamy więc inne elementy i cechy charakterystyczne dla szerokiej kategorii performansu i możemy o nich wnioskować w sposób dedukcyjny. Widzimy również właściwości wyróżniające.

Do najmocniejszych właściwości należy szczególna dbałość o: powszechność, wydajność, jakość, oszczędność, w tym oszczędność czasu, szybkość przepływu informacji, kompaktowość informacji, możliwość wpływu na sytuację kreacji i sytuację odbioru, możliwość filtrowania, zatrzymania, wyłączenia, odtworzenia, rejestracji, uczestnictwa i ingerencji z dystansu. Transmisja $\mathrm{z}$ użyciem mediów realizowana jest $\mathrm{w}$ czasie rzeczywistym i umożliwia równoczesny dostęp do śledzenia i bycia świadkiem danego wydarzenia. Komunikat nabiera charakteru masowego oraz, co szczególnie ważne przy śledzeniu etymologii samego słowa performance, komunikat dociera do każdego odbiorcy w tej samej jakości, umożliwiając równy dostęp do doświadczenia zapośredniczonego. Co więcej, przykłady transmisji na żywo (np. $\mathrm{z}$ konferencji $\mathrm{w}$ szerokim lub wąskim gronie $\mathrm{z}$ wykorzystaniem internetowego forum) otwierają się na komentarze i moderowanie osób fizycznie nieobecnych. Sama realizacja może być porównana do sztuki performance i sztuk performatywnych. Ich

${ }^{21}$ S.J. Baran, D.K. Davis, Teorie komunikowania masowego, dz. cyt., s. 347.

${ }^{22}$ M. McLuhan, Q. Fiore, J. Agel, The Medium Is the Message: An Inventory of Effects, Random House, New York 1967. 
rozróżnienie wywołuje często dezorientację, ale w tym przypadku dostarcza nam dodatkowych inspiracji w kwestii realizacji performansu medialnego.

Sztukę performance cechuje bezpośredniość, zachowuje ona margines na błędy, a nawet je integruje, biorąc za mocną stronę bezpośredniość, równoczesność i autentyczność (jak wiele wybaczamy komentatorom popełniającym gafy, którzy przeżywają emocje związane $\mathrm{z}$ wydarzeniem sportowym...). W sztuce performance do końca nie wiadomo, jaki będzie rezultat, ale całość bazuje na istotnym zamyśle, może korzystać z dowolnego kontekstu, podążać wraz obecnymi tam uczestnikami równolegle z procesem, dążyć do bezpośredniości, rejestrować zdarzenia symultaniczne nieprzewidziane, pozostawać otwartym na emocje, rozwój sytuacji. Wartość komunikatu jest często autoteliczna, szczególnie jeśli chodzi o gry olimpijskie czy mistrzostwa. Warto zaznaczyć, że rozmowa telefoniczna też będzie performansem medialnym, nie zakłada bowiem udziału wielu osób, mówi się nawet o połączeniu, chociaż dosłownie do niego nie dochodzi. Widać u początków wynalezienia telefonu tak odczuwano ten typ redukcji dystansu - jako szczyt technologicznych możliwości w tym zakresie.

Sztuki performatywne są oparte na scenariuszu, iterowalne, ćwiczone, wystudiowane w środowisku do tego przeznaczonym, odnoszą się do klasycznych gatunków artystycznych, jak balet, teatr, opera, większe znaczenie ma w nich opracowanie struktury oraz sposobu jej oddziaływania na odbiorcę. Umiejętne planowanie performansów medialnych stanowi zręczny element strategii wyborczych. Odpowiednio zrównoważone działanie performatywne odciąga uwagę odbiorcy od komunikatu potwierdzającego określoną wizję porządków lub nieporządków społecznych, nie tylko proponując alternatywę, ale też prowokując do samodzielnego myślenia. Szczegółowe opracowania w zakresie wywierania wpływu na ludzi, formułowania komunikatów perswazyjnych już powstały i kuszą wizją zdobycia korzyści.

$\mathrm{W}$ przekazach medialnych do wytwarzania potrzeb u swoich potencjalnych klientów używano nawet neurolingwistyki. Sama realizacja nie pozostaje bez znaczenia i pomimo przekazu w czasie rzeczywistym, dzięki użyciu technologii sposób kadrowania, zbliżenia ma oczywisty wpływ na kształtowanie odbioru szerszej publiczności. Co więcej, kampanie reklamowe wykorzystały konwencję performansu na żywo, np. reżyserując przerwanie trwającej czynności dnia codziennego, zaczepiając gospodynię domową wieszającą krystalicznie czyste pranie na sznurku w ogrodzie. To wszystko ma wpływać na poczucie autentyczności, które służy czystej perswazji. Inną jakością sztuk performatywnych, jak i drugiego wariantu performansów medialnych jest obecność kulis, która została opisana wyżej.

Ostatnią ciekawą jakością, na którą warto zwrócić uwagę, jest liminautyczność, która wiąże się z rozwojem sfery cyfrowej. Odnosi się ona do lokacji performansu, która sama pozostaje w przejściu, w przemianie - poza lub ponad granicami geopolitycznymi, wspólnotowymi, instytucjonalnymi, paradygmatycznymi, pokoleniowymi. Gdzie mieszają się konwencje, słowa, gesty, twierdzenia, systemy symboliczne w multimedialnych cyberprzestrzeniach? 


\section{Performance medialny jako performance delegowany}

Pojęcie performansu delegowanego przywołuję za Claire Bishop, która rozwija je przy okazji rozważań dotyczących akcji artystycznych. Jego właściwością jest to, że kto inny jest autorem, a kto inny go realizuje. Jest to o tyle przydatne, że w kontekście wcześniejszych rozważań o dwóch wariantach lokowania performansów medialnych nadaje się do omówienia performance budzący wiele emocji, przemocy i cierpienia, jakim są ataki terrorystyczne, a które cierpią zazwyczaj na deficyt głębszych analiz. Współcześnie dzięki rozwojowi technologii sposób nagłaśniania tych aktów przemocy ma daleko większy wpływ na potencjalną publiczność, o czym bardziej szczegółowo na przykładzie ataków z 11 września 2001 roku pisał już Richard Schechner ${ }^{23}$. Media mają niekwestionowaną przewagę w szybkości przepływu informacji. Jeżeli doniesienia i obrazy dotyczą spraw nagłego zagrożenia bezpieczeństwa i życia ludzi, którzy nie żyją na terenach objętych konfliktami zbrojnymi, co więcej, jeżeli akt ten spowodowany jest przez grupę ludzi bliżej niezidentyfikowaną, ale przynależącą do grup ideologicznych deklarujących opozycję do wartości i kultury Zachodu, to panika i strach opanowują taki obszar, jaki jest objęty przekazem medialnym.

Schechner krytykował brak świadomego podejścia do przekazywania tego typu doniesień przez media. Obrazy rodem z filmu sensacyjnego, który okazuje się jednak rzeczywistością, bez głębszej analizy i namysłu nad tymi zjawiskami wywołują taki rezultat, jaki terroryści pragną uzyskać. Jak przypomina Schechner, drugi samolot atakujący dwie wieże w Nowym Jorku nieprzypadkowo leciał z lekkim opóźnieniem. W tym czasie zauważono już pierwsze zderzenie, które zaczęto rejestrować, po czym pojawił się kolejny pilot samobójca, a drugie zderzenie $\mathrm{z}$ budynkiem utrwalono już od samego początku, zaś wiadomość momentalnie obiegła cały świat.

Claire Bishop skupia się głównie na akcjach artystycznych, ale jako przykład delegacji podaje też narzędzie outsourcingu wykorzystywanego w ekonomii i zarządzaniu ${ }^{24}$. Słowo „ekonomia” w kontekście ataków brzmi wyrachowanie i beznamiętnie, ale tak właśnie wykorzystana zostaje wiedza na temat funkcjonowania mediów we współczesnym świecie. O ile więc rozważając tego typu performance w kontekście wyróżnionych wcześniej wariantów lokowania, w pierwszym odruchu przyporządkowalibyśmy go do zastanej sytuacji stawania się, o tyle po głębszej refleksji i przeanalizowaniu motywów, którymi kierowali się sprawcy, performatyk dostrzeże tu sytuację wręcz wyreżyserowaną. Schechner pisał, że terroryści związani z Al-Kaidą bardzo dobrze orientują się we wpływie medialnych przekazów i mechanizmach ich działania ${ }^{25}$. W tej sytuacji, przez jednorazowy bolesny impuls, świadomie delegują na media informację do szerokiej publiczności w wielu

${ }^{23}$ R. Schechner, Performatyka, tłum. T. Kubikowski, Instytut im. Jerzego Grotowskiego, Wroclaw 2006.

${ }^{24}$ C. Bishop, Sztuczne piekła. Sztuka partycypacyjna i polityka widowni, tłum. J. Staniszewski, Fundacja Bęc Zmiana, Warszawa 2015, s. 399.

${ }^{25}$ R. Schechner, Performatyka, dz. cyt. 
krajach, donosząc, że działania ich są nie tylko straszne, lecz także niemożliwe do przewidzenia w kwestii miejsca i czasu. Oszczędzają przy tym inne zasoby, które należałoby uruchomić przy zwracaniu uwagi na takie zdarzenia. Miejsce może nie jest możliwe do przewidzenia, ale jak dotąd były to wielkie miasta i metropolie stanowiące często ważne ośrodki kulturalne i gospodarcze rozwiniętych państw. Bishop podnosi kwestię etyki w tego typu performansach związanych ze sztuką. Traktując perfomance medialny jako performance delegowany w przedstawionym przeze mnie przykładzie, kwestia etyki została całkowicie zdeptana, wymiar aktu przemocy i tragedii samego wydarzenia jest na tyle silny, że zawłaszcza całkowicie uwagę odbiorcy, który nie skupia się już na etyce działań towarzyszących.

[...] delegowany performance wytwarza wiele destabilizujących wydarzeń, które są dowodem istnienia wspólnej rzeczywistości widza oraz wykonawcy i stanowią zaprzeczenie utartych sposobów myślenia o przyjemności, pracy i etyce oraz odziedziczonych kategorii intelektualnych, za których pośrednictwem mielibyśmy rozumieć te idee dzisiaj ${ }^{26}$.

\section{Zakończenie}

Sam aspekt autoteliczny performansu medialnego może dotyczyć dwóch lokowań performansów. W przypadku kontekstowych typów dobrym przykładem będą mecze. Wartość ta przejmowana jest tu po właściwościach samej gry i zabawy, podobnie będzie ze sztuką i nałożeniem na niej ramy performansu medialnego. W przypadku konstruowania zaplecza medialnego do przekazu przykładem o wartościach autotelicznych będzie radio i wiele audycji, w tym choćby porannych, w których cała konstrukcja informacyjno-muzyczna nadawana na żywo, z komentarzem redaktora, stanowi medialny performance towarzyszący wstającym do pracy, czy tym, którzy utknęli w korkach na zakopiance, wracając $\mathrm{z}$ weekendu majowego. Społeczeństwo z perspektywy procesualnej to nieustanny ruch.

Możemy rozpocząć od dowolnej części modelu i prześledzić jego ewolucję w czasie. Którykolwiek komponent wybierzemy, widzimy go w funkcjonowaniu; każdy fakt okazuje się zdarzeniem; każdy podmiot można rozłożyć na działania, każdy stan jest jedynie fazą w zachodzącym procesie ${ }^{27}$.

Warto zaznaczyć, że performanse medialne rozpatrywane są łącznie z technologią, która tworzy ich jakości: wydajność, niezawodność, rezultaty. I chociaż wynalazki techniki, teorie komunikowania i kultura wizualna rozwijają się najsilniej $\mathrm{w}$ swoich osobnych torach, to oddziałują one zawsze jako całości i wzajemnie na siebie wpływają. W przyszłości integralne opracowania na ten temat dostarczyłyby pogłębionej, a przy tym praktycznej wiedzy na temat performansów medialnych.

${ }^{26}$ C. Bishop, Sztuczne piekła, dz. cyt., s. 411.

27 P. Sztompka, Socjologia zmian społecznych, dz. cyt. 


\section{Bibliografia}

Agamben. Przewodnik Krytyki Politycznej, Wydawnictwo Krytyki Politycznej, Warszawa 2009. Baran S.J., Davis D.K., Teorie komunikowania masowego, tłum. A. Sadza, Wydawnictwo Uniwersytetu Jagiellońskiego, Kraków 2007.

Bishop C., Sztuczne piekła. Sztuka partycypacyjna i polityka widowni, tłum. J. Staniszewski, Fundacja Bęc Zmiana, Warszawa 2015.

Goffman E., Człowiek $w$ teatrze życia codziennego, tłum. H. Datner-Śpiewak, P. Śpiewak, Wydawnictwo KR, Warszawa 2000.

McKenzie J., Performuj albo... Od dyscypliny do performansu, tłum. T. Kubikowski, Universitas, Kraków 2011.

McLuhan M., Fiore Q., Agel J., The Medium Is the Message: An Inventory of Effects, Random House, New York 1967.

Merton R.K., Social Research and Practicing Professions, Abt Books, Cambridge 1982.

Schechner R., Performatyka, tłum. T. Kubikowski, Instytut im. Jerzego Grotowskiego, Wroclaw 2006.

Sztompka P., Socjologia zmian społecznych, Znak, Kraków 2005.

Wachowski J., Performatyka, Słowo/Obraz Terytoria, Gdańsk 2011. 